Ilmu Dakwah: Academic Journal for Homiletic Studies Vol 10 No 2 Juli-Desember 2016 p-ISSN 1693-0843 http://journal.uinsgd.ac.id/index.php/idajhs DOI: http://dx.doi.org/10.15575/jid.v10i1.334

\title{
Peran Dakwah Masjid dalam Peningkatan Kualitas Hidup Masyarakat
}

\author{
Muhammad Qadaruddin", A.Nurkidam, dan Firman \\ Sekolah Tinggi Agama Islam Parepare \\ *qada_ruddin@yahoo.com
}

\begin{abstract}
Construction of the mosque not only pay attention to the physical building, but also must be optimized pemakmurannya. Efforts to raise the quality of life can be achieved by improving the Human Resources (HR) to carry out economic and social activities based mosques. This paper discusses How do standards of living and the mosque's role in public life, and how the role of the mosque in the village of Wonosasi improve people's lives, District Tapango, Polman. This study uses qualitative descriptive method, since it attempts to find the mosque's role in improving the welfare of the ummah. Research is needed to understand the organization's activities (mosque) in accordance with the wishes and needs of society.
\end{abstract}

Keyword : Role of Da'wa, mosques, Quality of Life Community

\begin{abstract}
ABSTRAK
Pembangunan masjid tidak hanya memperbatikan fisik bangunan, melainkan juga harus dioptimalkan pemakmurannya. Upaya meningkatka kualitas hidup masyarakat dapat dilakukan melalui peningkatan Sumber Daya Manusia (SDM) dengan melakukan kegiatan ekonomi dan sosial yang berbasis masjï. Tulisan ini membahas tentang Bagaimanakah taraf hidup masyarakat dan peran masjid dalam kehidupan masyarakat, serta bagaimanakah peran Masjid dalam meningkatkan kebidupan masyarakat Desa Wonosasi, Kecamatan Tapango, Kabupaten Polman. Penelitian ini menggunakan metode kualitatif deskriptif, karena berupaya menemukan peran masjid dalam meningkatkan kesejabteraan ummat. Penelitian diperlukan untuk dapat memahami kegiatan organisasi (masjid) yang sesuai dengan keinginan dan kebutuhan masayarakat.
\end{abstract}

Kata Kunci : Peran Dakwah, Masjid, Kualitas Hidup Masyarakat

Naskah diterima: 6 Sept 2016, direview 1 Nov 2016, disetujui: 14 Nov 2016

Ilmu Dakwah: Academic Journal for Homiletic Studies, Vol 10 No 2 | Juli - Des 2016 


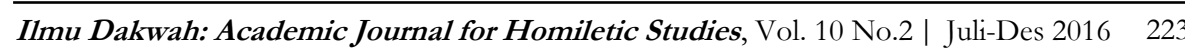


Muhammad Qadaruddin, dkk

\section{PENDAHULUAN}

Fungsi masjid pada dasarnya adalah tempat berkumpul dan tempat melaksanakan salat berjamaah, yang mencerminkan kebersamaan, solidaritas, dan silaturrahmi antar sesama umat Islam. Masjid merupakan tempat terbaik yang dianjurkan oleh Nabi Muhammad untuk melaksanakan salat Jumat.

Dalam bidang peningkatan sumber daya manusia, masjid dapat menjalankan peran penting sebagai sarana pengembangan wawasan keislaman melalui penyelenggaraan pengajian dan pendidikan, serta keterampilan yang diselenggarakan secara teratur atau secara rutin, berkenaan dengan acara tertentu, masjid merupakan pusat pencerahan dan pusat bimbingan bagi masyarakat yang berada di sekitarnya.

Masjid dapat menjalankan fungsinya sebagai pusat kegiatan social, di mana masyarakat bisa saling berjumpa, dan menjalin silaturahmi satu sama lain dalam memperkuat ikatan persaudaraan, bisa saling bertanya tentang kondisi masing-masing, terutama apabila salah seorang di antara mereka ada yang tidak mengikuti shalat berjamaah. Apabila sakit, akan dijenguk, bila sibuk diberitahukan, dan apabila lupa bisa diingatkan.

Masjid dapat digunakan sebagai tempat pelaksanaan berbagai kegiatan, yakni pembinaan kemampuan membaca dan menghafal AlQur'an, lembaga amil zakat, lembaga penengah sengketa, lembaga solidaritas, bantuan kemanusiaan, lembaga ekonomi dan lembagalembaga kursus keterampilan bagi anak-anak muda dalam berbagai ilmu pengetahuan. Masjid juga dapat digunakan sebagai sekretariat lembaga peduli perempuan, pengasuhan anak-anak sesuai dengan norma-norma agama Islam, lembaga pembinaan dan pengarahan bagi anak-anak dan melindungi mereka dari perilaku yang menyimpang.

Masjid memiliki kedudukan penting bagi umat Islam dalam upaya membentuk pribadi dan kepribadian masyarakat yang Islami. Dalam rangka mewujudkan peran penting itulah, masjid harus dapat diberdayakan atau difungsikan secara optimal.

Namun, hal yang penting ditekankan di sini, bahwa masjid yang harus dioptimalkan fungsinya secara baik ialah masjid-masjid yang dalam pembangunannya mengacu pada dasar ketakwaan.

Fungsi masjid sebagai pusat pembinaan umat Islam haruslah mendapat perhatian serius di kalangan umat Islam. Pengembangan masjid sebagai pusat-pusat kegiatan spiritual dan ekonomi umat untuk membentuk manusia seutuhnya yang berakhlak al-karimah (berbudi pekerti yang luhur sejalan dengan nilai-nilai kesopanan, tatakrama) melalui pelaksanaan ibadah salat dan kegiatan-kegiatan keagamaan

224 Ilmu Dakwah: Academic Journal for Homiletic Studies, Vol. 10 No.2 | Juli-Des 2016 
lainnya yang diselenggarakan di dalam masjid adalah sebuah keniscayaan yang harus mendapat perhatian utama dan diwujudkan dalam kegiatan sehari-hari. (Achmad \& Achmad, 2010: 9)

Sebagai muslim, kita tidak boleh merasa puas dengan hanya menyaksikan keberhasilan pembangunan masjid yang megah dan elegan pada arsitekturnya yang menelan biaya ratusan juta bahkan milyaran rupiah, karena dalam pembangunan masjid, selain bentuk fisiknya yang megah juga harus dibarengi dengan pegembangan kuantitas dan kualitas jamaah.

Pembangunan masjid tidak hanya memperhatikan fisik bangunan, melainkan juga harus dioptimalkan pemakmurannya. Jangan sampai sebuah masjid yang dibangun dengan megah dan indah serta menghabiskan dana yang besar, namun tidak banyak umat yang memakmurkan masjid.

Untuk dapat mengoptimalkan peran dan fungsi masjid pada masa sekarang ini, Menurut Farid, "Masjid dalam peradaban Islam, bukan sekadar sebuah tempat kegiatan keagamaan dan kebudayaan, tetapi merupakan suatu tata kelembagaan yang menjadi sarana pembinaan masyarakat dan keluarga muslim serta insan-insan peradaban Islam" (Farid, 1997: 205).

Secara fisik, bangunan masjid di setiap daerah sudah baik, bahkan dana yang terkumpul dari masyarat cukup banyak. Namun pemanfaatannya kadang-kadang hanya untuk perbaikan fisik saja. Sering kita melihat masjid yang bangunannya megah tetapi jamaah yang masuk dan beraktifitas di masjid sangat sedikit. Ada pula masjid yang sudah jadi kemudian dibongkar lagi untuk di bangun kembali. Hal itu membuktikan bahwa dana yang dimiliki oleh masjid yang terkumpul dari masyarakat sangat banyak. Hanya saja pengelolaan dan penggunaannya hanya sebatas pada pembangunan fisik, belum menyentuh pada pengembangan ekonomi dan kegiatan produktif dan sosial lainnya.

Jika dilihat dari sisi jumlah jamaah dan keuangan masjid maka potensi yang dimiliki oleh masjid sungguh sangat luar biasa. Namun, taraf hidup dan kualitas hidup masyarakat belum bisa ditopang oleh potensi yang dimiliki oleh masjid dan masyarakat itu sendiri. Oleh karena itu, perlu ada upaya yang dilakukan untuk memberdayakan ekonomi dan kualitas hidup masyarakat yang berbasis masjid. Dengan demikian, potensi yang dimiliki oleh masjid dapat dikembangkan untuk meningkatkan kualitas hidup masyarakat, baik dari sisi ekonomi maupun peribadatan.

Ilmu Dakwah: Academic Journal for Homiletic Studies, Vol. 10 No.2 | Juli-Des 2016225 
Upaya meningkatka kualitas hidup masyarakat dapat dilakukan melalui peningkatan Sumber Daya Manusia (SDM) dengan melakukan kegiatan ekonomi dan sosial yang berbasis masjid. Potensi masjid dapat diberdayakan dengan meningkatkan pengelolaan manajemen dan keuangan yang dapat menumbuhkan perekonomian jamaah melalui berbagai usaha produksi dan pembiayaan yang bersumber dari keunganan masjid.

Perwujudan dalam memakmurkan masjid bukan hanya melakukan renovasi masjid, membangun masjid yang mengah, akan tetapi wujud memakmurkan masjid dengan cara senantiasa masjid menjadi pusat kegiatan ibadah, baik kegiatan social, ekonomi dll, memakmurkan masjid diwujudkan dengan meningkatnya kuantitas dan kualitas jamaah. Memakmurkan masjid di bidang Idarah (kegiatan administrasi) mengadakan musyawarah, menentukan program kerja, Memakmurkan masjid di bidang imarah (kegiatan kemakmuran) mendirikan salat jamaah, TPA dan majelis taklim, Memakmurkan masjid di bidang ri'ayah (kegiatan sarana-prasarana), tanah wakaf telah bersertifikat, air yang bersih, taman, petugas kebersihan.

Desa Batu Kecamatan Tapango, Kabupaten Polman ditemukan dua masjid dalam satu desa yang memiliki bangunan yang cukup bagus tetapi jamaahnya hanya dua atau tiga orang. Itu pun hanya pada waktuwaktu tertentu saja dilakukan salat berjamaah, terutama hanya magrib, isya, dan subuh saja. Hal ini terjadi, di samping karena pengelolaan yang tidak didukung oleh SDM memadai, juga karena tidak adanya kegiatankegiatan yang dapat membantu masyarakat dalam mengatasi persoalan yang dihadapi, seperti kegiatan ekonomi yang produktif dengan sumber pembiayaan yang dikelola oleh masyarakat yang berbasis masjid.

Berdasarkan pada observasi tersebut tersebut, maka muncul beberapa pertanyaan yang berkaitan dengan judul penelitian ini, yaitu: Bagaimanakah taraf hidup masyarakat dan peran masjid dalam kehidupan masyarakat, serta bagaimanakah peran Masjid dalam meningkatkan kehidupan masyarakat Desa Wonosasi, Kecamatan Tapango, Kabupaten Polman.

Penelitian ini menggunakan metode kualitatif deskriptif, karena berupaya menemukan peran masjid dalam meningkatkan kesejahteraan ummat. Penelitian diperlukan untuk dapat memahami kegiatan organisasi (masjid) yang sesuai dengan keinginan dan kebutuhan masayarakat. Secara lebih terperinci data yang diperlukan dalam penelitian ini dapat

226 Ilmu Dakwah: Academic Journal for Homiletic Studies, Vol. 10 No.2 | Juli-Des 2016 
berupa: catatan tentang pandangan dan gagasan, rekaman wawancara, catatan pengamatan, buku harian, foto, film, dokumen, dan tulisan dalam majalah atau surat kabar, sesuatu yang didengar, dilihat, diuji coba dan direfleksikan oleh peneliti.

Kajian ini menggunakan teori system sebagai road map yang memandang organisasi sebagai kaitan bermacam macam komponen yang saling tergantung satu sama lain dalam mencapai tujuan organisasi, setiap bagian mempunyai peranan masing-masing dan berhubungan dengan bagian-bagian lain dan karena itu koordinasi penting dalam teori ini.

Teori sietem yang umum mengatakan bahwa organisasi sebagai suatu set bagian-bagian yang kompleks yang saling berhubungan dan berinteraksi untuk menyesuaikan diri dengan lingkungannya yang selalu berubah agar mencapai tujuannya (Arni, 2014: 47). Masjid sebagai system dalam suatu masyarakat bukan sekedar berperan sebagai tempat ibadah, akan tetapi memiliki peran dalam meningkatkan kesejahteraan social, masjid merupakan tempat sentral kegiatan masyarakat, sehingga masjid perlu disesuaikan dengan kondisi keummatan.

\section{HASIL DAN PEMBAHASAN}

Pada awalnya Masjid al-Aqsha Batu merupakan masjid yang didirikan oleh pemerintah sebagai fasilitas pemukiman kembali (transmigrasi lokal). Bangunan masjid hanya dalam bentuk semi permanen yang berukuran 5x6 meter persegi. Masjid tersebut berlokasi dalam satu area yang berdampingan dengan gereja. Pada tahun 1987, atas inisiatif jamaah dan tokoh masyarakat masjid Aqso dipindahkan pada lokasi yang lebih luas dengan tanah wakaf dari salah seorang jamaah pemilik lahan perkebunan. Bangunan masjid pertama didirikan dengan dana gorong royong masyarakat desa Batu. Bangun masjid sudah permanen, namun ukuran dan bentuknya tidak memadai. Akhirnya pada tahun 2012 diadakan pemugaran total dengan membangun kembali yang baru. Sumber dana diperoleh dari berbagai sumber, baik dari sumbangan jamaah maupun dari sumbangan tokoh masyarakat dan dari beberapa tokoh kader partai politik.

Yang menarik dari pembangunan dan awal pemindahan masjid karena diprakarsai oleh tokoh masyarakat yang baru masuk Islam sebagai muallaf, yaitu Bapak Tukiman yang telah diikuti 60 orang muallaf untuk masuk Islam tanpa paksaan. Pada awalnya masuknya 60 orang muallaf menjadi polemik di masyarakat karena ada laporan dari tokoh agama Kristen yang keberatan atas masuknya warga yang dinilai 
fenomenal tersebut. Hal tersebut dianggap sebagai pengaruh dari Bapak Tukiman.

"Awal renovasi dan relokasi masjid ini karena usulan beberapa jamaah dan direspon oleh Bapak H. Hamaron untuk mewakafkan lahannya. Saya sudah terlibat karena baru masuk Islam pada waktu itu. Atas dasar keinginan sendiri yang dibimbing oleh mahasiswa KKN STAI DDI saat itu. Setelah saya masuk Islam disusul oleh 60 orang ikut masuk Islam. (Wawancara dengan Tukiman, 29-112015)

Dari wawancara di atas tergambar bahwa awal mula berdirinya masjid Aqsha di desa Batu (Wonosari) Kecamatan Tapago, atas prakarsa tokoh masyarakat muallaf dan dakwah yang dilakukan oleh mahasiswa KKN STAI DDI, serta karena adanya hidayah Allah, ini dapat dilihat dalam waktu yang tidak lama ada sekitar 60 keluarga yang masuk Islam. Atas dasar itulah sehingga pada awalnya nama masjid tersebut dinamai dengan masjid "Muallaf".

Masjid Aqsa juga dapat menjalankan fungsi sebagai tempat berkumpul dan tempat melaksanakan salat berjamaah yang mencerminkan kebersamaan, solidaritas, dan silaturrahmi antar sesama umat Islam.

"Masjid Aqsha, hanya dipakai melaksanakan salat lima waktu dan salat Jumat, itupun penceramahnya hanya warga masayarakat, tapi kalau ada pegawai KUA maka dia yang khutbah Jumat". (Wawancara dengan Gufran, 29-11-2015)

Selama ini Pengurus Masjid Aqsha masih kurang memahami tentang manajemen masjid. Hal tersebut terbukti dari tidak adanya pengelolaan dai untuk kegiatan khutbah Jumat sehigga hanya diisi oleh jamaah yang bisa baca khutbah. Untuk manajemen dai, pengurus masjd dapat menyusun jadwal setiap tahun, sehingga terlaksana perencanaan dakwah, jika jadwal dai tidak direncanakan akan berdampak terhadap efektivitas dan kualitas pelaksanan salat jumat. Masjid bukan hanya tempat salat wajib, akan tetapi masjid merupakan tempat pendidikan, pelayanan sosial, perekonomian. Kurangnya manajemen sumber daya manusia pada masjid Aqsha dapat dilihat ketika peneliti ke masjid untuk salat zuhur, akan tetapi peneliti tidak melihat aktivitas salat berjamaah, peneliti hanya melihat jamaah datang secara bergantian.

228 Ilmu Dakwah: Academic Journal for Homiletic Studies, Vol. 10 No.2 | Juli-Des 2016 
Selain menjadi tempat salat berjamaah, baik berupa salat Jumat maupun salat lima waktu, masjid memiliki peran yang sangat penting dalam mencerdaskan umat. Khutbah Jumat, merupakan momen penting untuk menyampaikan pesan, pengarahan, peringatan dalam rangka peningkatan takwa kepada Allah Swt. Sehingga masjid juga perlu memiliki SDM yang dapat menyampaikan nasihat-nasihat atau materimateri keagamaan yang bersifat mendidik, tentang kewajiban-kewajiban yang harus dilakukan secara terus menerus oleh kaum Muslimin, masjid Aqsa belum memanfaatkan da'i-da'i dari luar, namun masih menggunakan penceramah setempat, karena memang terkendala persoalan letak masjid yang jauh dari perkotaan sehingga sangat susah dijangkau oleh para dai. Seperti yang dijelaskan Gufran, bahwa di masjid Aqsa kurang penceramah, sehingga yang ceramah hanya dari masyarakat secara bergantian dan jarang menggunakan penceramah dari luar.

Dalam bidang peningkatan sumber daya manusia, masjid dapat menjalankan peran penting sebagai sarana pengembangan wawasan keislaman melalui penyelenggaraan pengajian dan pendidikan keterampilan yang diselenggarakan secara teratur atau secara rutin berkenaan dengan acara tertentu, sehingga masjid merupakan pusat pencerahan dan pusat bimbingan bagi masyarakat yang berada di sekitarnya. Di Masjid Aqsa ini kadang-kadang ada pengajian, biasanya kegiatan majelis taklim yang dilakukan pada malam hari, dan diikuti oleh jamaah perempuan dan laki-laki. (wawancara dengan Gufron 2015)

Pengembangan kegiatan masjid, berupa kegiaan sosial ekonomi dan aktivitas-aktivitas keagamaan, baik dalam bentuk pengajian, ceramahceramah, maupun pembekalan pendidikan agama bagi anak-anak dan generasi muda, dan keterampilan memiliki arti penting. Masjid Aqso selama ini hanya bias melaksanakan kegiatan shalat dan yasinan, belum ada TPA. Anak-anak hanya belajar mengaji di rumah penduduk saja.

Untuk dapat mengoptimalkan peran dan fungsi masjid pada masa sekarang ini, harus mengetahui terlebih dahulu bagaimana masjid difungsikan pada masa Nabi Muhammad saw. Sebagaimana yang dikehendaki oleh Allah SWT., peran dan fungsi masjid pada masa rasulullah ini sangat penting untuk diketahui agar tidak menyimpang dalam memfungsikan masjid dari tujuan awal didirikannya. Menurut Farid, "Masjid dalam peradaban Islam, bukan sekadar sebuah tempat kegiatan keagamaan dan kebudayaan, tetapi merupakan suatu tata kelembagaan yang menjadi sarana pembinaan masyarakat dan keluarga muslim serta insan-insan peradaban Islam" (Farid, 1997: 205). 
Masjid memiliki fungsi yang sangat penting bagi masyarakat, masjid sebagai sub system, sub-sub sistem yang satu sama lainnya saling melakukan pertukaran, misalnya antara masjid dan kantor kelurahan, maupun KUA, sehingga menjalin sinergi antara sub system, bilamana beberapa bagian yang berlainan dan berbeda satu sama lain membentuk suatu kesatuan, melaksanakan hubungan fungsional yang tetap satu sama lain serta mewujudkan bagian-bagian itu saling tergantung satu sama lain. Sehingga kerusakan suatu bagian mengakibatkan kerusakan keseluruhan, maka hubungan yang demikian disebut sistem. http:/ / taufiknurohman25.blogspot.co.id/2011/04/teori-sistem-davideaston.html

Masjid sebagai system social dapat mempengaruhi tingkat ekonomi, budaya dan politik masayarakat, sehingga penelitian ini menggambarkan pola hubungan antara pengurus masjid, pemerintah, masyarakat.

\section{Peran dan Fungsi Masjid Al-Aqso}

Pada Masjid Al-Aqsha memiliki beberapa peran dan fungsi, antara lain, Pertama, sebagai tempat pelaksanaan peribadatan. Masjid Al-Aqsha Batu sejak awal didirikan telah difungsikan sebagai tempat beribadah masyarakat Tapago, terutama jamaah masjid al-Aqsha yang dominan muallaf sangat antusias dalam melaksanakan ibadah sholat, meskipun bangunan masih kurang baik (belum permanen), realitas ini dapat dilihat dari kuantitas dan kualitas jamaah yang tidak berkurang.

Kedua, sebagai tempat pertemuan, pada zaman Nabi Muhammad SAW, masjid menjadi tempat pertemuan atau convention center yang dipergunakan oleh Nabi Muhammad dalam pertemuan-pertemuan penting bersama para sahabatnya secara rutin. Masjid menjadi tempat bertemu antar jamaah, tampa melihat umur, etnis, pendidikan, jabatan, masjid menjadi tempat pertemuan, tempat pelaksanaan kegiatan-kegiatan keagamaan, ekonomi, social, sehingga masjid dapat berperan penting dalam peningkatan kualitas masyarakat.

Keempat, sebagai tempat kegiatan Sosial. Pada hari hari besar Islam masjid Al-Aqsha melaksanakan kegiatan keagamaan seperti halnya pada masjid pada umumnya Masjid sebagai komponen fasilitas sosial ialah salah satu fasilitas yang merupakan bangunan tempat berkumpul bagi sebagian besar umat Islam untuk melakukan ibadah sebagai kebutuhan spiritual yang diperlukan oleh ummat manusia, di samping kebutuhan material. Dengan demikian, agar kesejahteraan material dan spiritual dapat dicapai maka fasilitas-fasilitas untuk memenuhi kedua kebutuhan

230 Ilmu Dakwah: Academic Journal for Homiletic Studies, Vol. 10 No.2 | Juli-Des 2016 
tersebut harus tersedia secara memadai di dalam suatu lingkungan. (Rukmana: 2002)

Kelima, tempat pembinaan umat dan kegiatan Dakwah Islamiyah. Masjid dan dakwah Islamiyah merupakan dua faktor yang memiliki kaitan erat satu sama lain, saling isi mengisi di antara keduanya, kalau diumpamakan laksana gudang dengan barangnya. Masjid amat besar fungsinya dalam dakwah, baik dakwah yang dilakukan oleh Rasulullah kepada para sahabatnya, maupun antar sesama sahabat. Oleh karena itu, dakwah merupakan suatu yang sangat mulia dalam Islam dan masjid menjadi sarana utamanya. Pada masyarakat Desa Batu, Kec. Tapango, Peran masjid sebagaimana hasil wawancara adalah sebagai tempat ibadah dan pengajian, fungsi dan peran masjid masih kurang sebagai lembaga masayarakat, bila dibandingkan masjid-masjid lain, apalagi masjid ketika zaman Rasululllah Saw.

Peran Masjid Aqsha yang paling utama yaitu sebagai lembaga peribadatan. Hal tersebut tidak dapat dipungkiri karena tujuan dari pendirian Masjid Aqsha tersebut yang utama adalah agar digunakan sebagai tempat salat. Peranan masjid sebagai lembaga peribadatan tersebut ditunjang data yang peneliti dapatkan. Masjid didirikan oleh masyarakan desa Batu sebagai sarana ibadah. Peran Masjid Aqsha sendiri belum banyak, namun baru kegiatan-kegiatan ibadah dan pengajian.

Melihat kebutuhan masyarakat Desa Batu, sesungguhnya fungsi Masjid Aqsha ini banyak sekali, yakni selain masjid ini digunakan untuk beribadah, juga dapat digunakan sebagai peningkatan iman dan pengetahuan dan fungsi-fungsi sosial dan ekonomi. Berdasarkan wawancara dengan pengurus Masjid Aqsha diketahui bahwa di masjid ini, kadang-kadang diadakan pengajian oleh majlis taklim. Namun, kegiatan ekonomi dan pengembangan sumberdaya manusia belum pernah dilakukan. Hal tersebut menunjukkan bahwa masjid belum berfungsi sebagai basis pengembangan ekonomi dan sumberdaya umat.

Statemen bahwa Masjid Aqsha sebagai lembaga ibadah diperkuat dengan adanya berbagai kegiatan keagamaan yang dilaksanakan di masjid tersebut. Dari data yang terkumpul di atas, dapat disimpulkan bahwa masjid Aqsha berperan sebagai lembaga ibadah dengan bukti adanya aktivitas untuk melaksanakan salat. Disamping itu, di masjid Aqsha diadakan berbagai kegiatan-kegiatan keagamaan sebagai penunjang ibadah harian dan penguatan keimanan.

Realitas social masayarakat tapago belum memberikan konstribusi besar terhadap pembangunan masjid, masyarakat belum 
merasa bahwa masjid al-aqsha merupakan masjid Allah, dan setiap muslim berhak untuk beribadah di dalamnya, termasuk belum adanya sinergi antara kepala desa dan pengurus masjid, sehingga terkadang terjadi kesalahpahaman dalam pengambilan keputusan. Peneliti melihat perlunya melakukan komunikasi yang efektif dalam bentuk dialog, musyawarah antara pemerintah dan masayarkat, serta pengurus masjid agar tidak terjadi saling mencurigai, agar masjid dapat difungsikan sebagaimana seharusnya.

Masjid Aqsha, selain berfungsi sebagai lembaga ibadah atau lembaga peribadatan, juga berfungsi sebagai lembaga dakwah. Selain diadakan pengajian, untuk menunjang peran masjid sebagai sarana dakwah, maka biasa diadakan berbagai kegiatan. Namun masjid al-Aqsha perlu diperhatikan dari segi peningkatan kualitas jamaah dan fasilitas seperti quran dan alat-alat shalat. Masjid al-Aqsha ini juga berperan sebagai lembaga dakwah, terbukti dengan adanya kegiatan-kegiatan untuk mensyiarkan Islam dan membangkitkan semangat beribadah, yang berupa kegiatan pengajian majelis taklim, walaupun belum secara rutin dan kontinu.

Peran masjid yang berikutnya adalah sebagai lembaga kemasyarakatan. Hal ini sangat penting dalam masyarakat dan hanya sedikit sumber yang menyatakan mengenai hal tersebut. Data yang peneliti dapatkan mengenai hal tersebut antara lain, masjid seharusnya menjadi pusat perekonomian misalnya saja di masjid dapat dibentuk BMT (Baitul Mal Wa Tanwil) yang berfungsi untuk mengembangkan ekonomi masayarakat, selain itu masjid dapat difungsikan untuk kegiatan pengembangan keterampilan dan bebebrapa aktivitas masayarakat. Masjid yang secara fisik sudah baik maka yang perlu dilakukan lagi adalah masjid menjadi tempat pendidikan, tempat pelatihan kreativitas, tempat simpan pinjam bagi masayarkat yang membutuhkan modal. Namun, yang terjadi pada beberapa masjid, pengelolaan keuangan hanya digunakan untuk renovasi, misalnya saja setiap tahun keramik masjid diganti, menambah aksesoris, tanpa mempedulikan kesejahteraan jamaah, dan pengurus masjid.

Sebenarnya, peran masjid sebagai lembaga kemasyarakatan sudah termasuk ke dalam peran masjid sebagai lembaga ibadah, yaitu ketika salat berjamaah, kedudukan antara makmum satu dengan yang lainnya sama tanpa memperhitungkan pangkat, kedudukan maupun martabat. Jadi, antara satu dengan yang lainnya dapat bertegur sapa tanpa beban dan hambatan yang berarti karena mereka sama-sama menanggalkan kedudukan dan derajat keduniaan mereka.

232 Ilmu Dakwah: Academic Journal for Homiletic Studies, Vol. 10 No.2 | Juli-Des 2016 


\section{Manajemen Masjid Al-Aqso}

Perencanaan pembangunan masjid merupakan proses awal yang harus ditetapkan. Rencana harus diwujudkan serta mempertimbangkan kebutuhan fleksibilitas, agar lokasi masjid mampu menyesuaikan dengan situasi dan kondisi secepat mungkin. Masjid al-Aqso pada Awal mula berdirinya terletak di dekat gereja, tapi ada warga yang mewakafkan tanahnya untuk pendirian masjid, jadi tempatnya dipindahkan.

Salah satu aspek penting dalam perencanaan awal pembangunan masjid adalah pembuatan keputusan (decision making), proses pengembangan dan penyelesaian sekumpulan kegiatan untuk memecahkan suatu masalah tertentu. Perencanaan pembangunan masjid seyogyanya dilakukan melalui empat tahap perencanaan: Pertama, Menetapkan tujuan pembangunan masjid atau serangkaian tujuan didirikannya masjid, artinya, masjid yang akan dibangun harus berlandaskan pada spiritual benefits yang mengacu pada terwujudnya ketaqwaan dan kesalehan, bukan berlandaskan persaingan (riya) atau mematikan masjid lain dalam menjalankan peran dan fungsinya, yang dimaksud dengan persaingan ialah sebuah masjid yang dibangun atas dasar emosi guna mencari pengaruh pribadi dikalangan masyarakat. Tujuan pembangunan masjid seperti ini biasanya masjid yang dibangun oleh individu-individu di perkampungan setelah terjadinya konflik atau beda pendapat dengan tokoh/imam masjid setempat).

Pembangunan Masjid al-Aqso tujuan awalnya adalah untuk memberikan wadah bagi muallaf untuk tempat ibadah, adanya tokoh masyarakat non muslim yang masuk islam menyebabkan banyaknya muallaf.

Pembangunan masjid juga bertujuan mengaktifkan kembali peranperan masjid yang pernah ada pada zaman Rasulullah. Merumuskan keadaan saat pembangunan masjid, Merumuskan situasi dan kondisi saat pembangunan masjid, merupakan hal penting dalam membangun masjid. Masjid al-Aqso rencana awalnya berada di dekat gereja, namun sepertinya kurang baik kalau terlalu dekat, apalagi yang jamaahnya muallaf, kebetulan waktu itu ada orang tua yang mau mewakafkan tanahnya untuk pembangunan masjid, tanah itu tempatnya sangat strategis, berada di pusat desa, hanya saja sampai sekarang belum ada bukti wakafnya.

Pembangunan masjid dekat geraja kurang baik, kurang strategis apalagi jamaahnya muallaf, dikhawatirkan ada rasa tidak saling menghormati, begitupula Pembangunan masjid yang berdekatan dengan masjid yang ada tidak dapat memberikan kontribusi apapun terhadap 
masyarakat muslim jika penduduk kota/desa di mana masjid baru yang dibangun tidak memiliki jumlah populasi padat, sehingga masjid yang ada sudah menampung seluruh kaum muslimin dalam menjalankan salat, baik salat jumat maupun salat lima waktu secara berjamaah. Ketiga, mengidentifikasikan segala kemudahan dan kesulitan atau hambatan. Keempat, mengembangkan rencana atau serangkaian kegiatan, Tujuan utama perencanaan awal pembangunan masjid adalah untuk melihat program-program dan penemuan-penemuan terkini agar dapat dipergunakan untuk meningkatkan kemungkinan pencapaian tujuan di waktu yang akan datang, yaitu meningkatkan pembuatan keputusan yang paling baik. Perencanaan seperti ini diperlukan sehubungan dengan dua alasan utama untuk mencapai tujuan utama, yaitu; Protective Benefits, yang dihasilkan dari pengurangan kemungkinan terjadinya kesalahan dalam pembuatan keputusan dan Positive Benefits dalam bentuk meningkatnya pencapaian tujuan organisasi. (Wijayakusuma dan Yusanto: 33-34).

Sumber daya yang dimiliki organisasi atau lembaga, termasuk manajemen masjid, dapat dikategorikan atas empat tipe sumber daya, yakni sumber daya keuangan, sumber daya manusia, sumber daya kemampuan teknologi, serta penguasaan para anggota pengurus terhadap peralatan modern dan komunikasi. (Simamora, 1995: 1)

Perencanaan terjadi di segala kegiatan, "kegiatan tanpa perencanaan akan pincang, sedangkan perencanaan tampa kegiatan adalah sesuatu yang nonsense." Perencanaan adalah proses dasar dimana seorang ketua memutuskan tujuan dan cara mencapainya. Jadi, perencanaan adalah pemilihan sekumpulan kegiatan dan mengetahui apa yang selanjutnya harus dilakukan, kapan, bagaimana, dan oleh siapa. Perencanaan yang baik dapat dicapai dengan mempertimbangkan kondisi https://club3ict.wordpress.com/2011/02/18/perencanaan-dan-

pengorganisasian-kegiatan/

pada waktu yang akan datang, di mana perencanaan dan kegiatan yang diputuskan akan dilaksanakan, serta periode sekarang pada saat rencana itu dibuat.

Pengorganisasian manajemen masjid berarti mengkoordinasikan sumber daya keuangan dan sumber daya manusia yang akan ditempatkan dalam kepengurusan masjid, serta sumber material masjid. Sumber material masjid artinya sebuah proses pengaturan kerja bersama sumber daya keuangan, atau fisik dan manusia yang tergabung dalam struktur organisasi masjid. Sumber daya manusia yang tergabung dalam organisasi masjid menjadi unsur penting dalam

234 Ilmu Dakwah: Academic Journal for Homiletic Studies, Vol. 10 No.2 | Juli-Des 2016 
keberhasilan ta'mir masjid atau tidaknya. Sumber daya yang dimiliki organisasi atau lembaga termasuk manajemen masjid dapat dikategori

Membicarakan struktur personal manajemen masjid berarti membicarakan sebuah organisasi yang masuk ke dalam pembicaraan kata benda yang abstrak. Dalam arti kata, bahwa ikatan benda tersebut sebenarnya tidak ada, tetapi dianggap dan dirasakan seolah-olah ada. Oleh karena itu, dlam Al-Qur'an tidak pernah menyebut-nyebut tentang organisasi. Penyebutan yang terdapat dalam Al'Quran banyak dijumpai kata kaum dalam beberapa ayat pada surat yang berbeda-beda. Kata kaum tidak jauh berbeda dengan organisasi, karena mengindikasikan adanya seorang pemimpin, yakni para nabi dan yang dipimpinnya, yakni sekelompok manusia dibawah kepemimpininan para Nabi dan Rasul. Pada masjid Al-Aqsha terdapat struktur organisasi, akan tetapi belum di SK kan secara formal, pada dinding masjid al-Aqsha belum terpasang struktur kepengurusan, sehingga pembagian kerja dan koordinasi antara pengurus dan jamaah tidak terlaksana dengan baik.

Dimanapun masjid didirikan, fungsi dan peranan yang diembannya sama saja, baik masjid yang terdapat di kota-kota besar maupun di desa-desa. Masjid adalah tempat untuk beribadah, khususnya untuk mendirikan shalat yang wajib ataupun yang sunah setidak-tidaknya lima kali sehari semalam, dari situ dikumandangkan seruan adzan. Program-program kerja manajemen masjid atau kegiatan-kegiatan lain yang juga melembaga didalam masjid adalah: 1. Belajar mengaji buat anak-anak. Biasanya dilakukan setelah shalat Maghrib dengan menggunakan kitab turutan atau alip-alipan, yang terkadang disebut juga "Qur'an Kecil"; 2. Mengumpulkan dan membagikan zakat fitrah; 3. Menyelenggarakan peringatan Isra' Mi'raj, Maulid Nabi, dan khataman alQur'an (syukuran bagi anak-anak yang telah tamat membaca Al-Qur'an); 4. Sekalipun belum merata di semua masjid, di beberapa tempat secara teratur diselenggarakan pengajian-pengajian khusus bagi kaum ibu. (Ayub, 2001: 39)

Masyarakat Desa Wonosari Kec. Tapango sudah mulai melakukan pembenahan program kerja meskipun pada saat peneliti dilapangan belum melihat program kerja yang dipajang di dinding masjid, begitu pula ketika peneliti menayakan tentang data program kerja, pengurus masjid belum mampu menunjukkan datanya, akan tetapi kegiatan ibadah salat dan pengajian sudah terlaksana untuk TPA masih di rumah penduduk, yang biasanya dilakukan di masjid. Penyusunan program kerja harus melakukan koordinasi dengan berbagai elemen masyarakat a di desa-desa, tanpa koordinasi dengan aparat/kantor 
kelurahan setempat. Kerjasagar supaya program kerja dapat meningkatkan kesejahteraan jamaah, sehingga dapat meningkatkan kualitas dan kuantitas jamaah.

Kegiatan-kegiatan tersebut, dilakukan di dalam masjid atau langgar-langgar (musallah)ma antarmasjid, seperti tukar menukar pengalaman, saling bantu dalam masalah pendidikan, pinjam-meminjam kitab atau buku dapat dikatakan tidak pernah terjadi. Orang sudah merasa puas apabila masjidnya sudah dapat dipergunakan untuk salat, belajar mengaji, dan menunaikan kewajiban zakat.

Menjadi pengurus masjid, bukanlah suatu pekerjaan yang ringan. Tugas dan tanggungjawabnya cukup berat. Terlebih lagi dia tidak memperoleh gaji dan imbalan yang memadai, dia harus pula rela mengorbankan waktu dan tenaganya. Adapun tugas dan tanggung jawab pengurus masjid meliputi: memelihara masjid, mengatur kegiatan, membuat rencana kerja masjid, seperti : a) ibadah shalat Jumat b) pengajian atau ceramah c) menyelenggarakan pelatihan/kursus pendidikan dasar. (Ayub, 2001:39)

Di beberapa masjid, ta'mir masjid mendapatkan kesejahteraan setiap bulan meskipun masih kurang dari cukup karena setiap bulan hanya mendapatkan sekitar 200 ribu, dan pemerintah daerah menganggarkan bagi setiap imam masjid untuk dapat melaksankan umrah, dan ini dilaksanakan secra bertahap, akan tetapi masjid di desa wonosari ini masih kurang diperhatikan dari segi peningkatan kualitas pengurus masjid dan ta'mir masjid, belum ada program pemerintah yang dapat meningkatkan motivasi ibadah, sehingga secara realitas pengurus masjid dan ta'mir masjid belum maksimal dalam peningkatan kualitas SDM yang ada hanya peningkatan kualitas fisik masjid.

Struktur organisasi masjid adalah susunan unit-unit kerja yang menunjukkan hubungan antar unit, adanya pembagian kerja sekaligus keterpaduan fungsi-fungsi atau kegiatan-kegiatan yang berbeda-beda tersebut, dan adanya wewenang, garis pemberian tugas, dan laporan. Di Masjid Al-Aqso, pembentukan pengurus masjid dilakukan melalui rapat tapi, meskipun belum ada SK pengurusnya, akan tetapi sudah ada pembagian kerja pengurus.

Pengurus masjid Aqsha kurang paham tentang prosedur pengajuan SK pengurus masjid, karena kurangnya koordinasi antara pemerintah dan pengurus masjid, sehingga sampai saat ini belum ada SK pengurus masjid, yang ada hanya penunjukan hasil rapat, sehingga peneliti tidak mendapatkan SK pengurus masjid serta di masjid belum ada tertempel struktur pengurus masjid.

236 Ilmu Dakwah: Academic Journal for Homiletic Studies, Vol. 10 No.2 | Juli-Des 2016 
Struktur organisasi masjid ini dapat disederhanakan atau dikembangkan sesuai dengan program dan tujuan dari sebuah masjid yang mungkin berbeda antara satu masjid dengan masjid lainnya tergantung juga kepada mekanisme kerja organisasi masjid tersebut. Sebagai ilustrasi dapat disampaikan di sini sebagai berikut. (Supardi dan Amrudin, 2001: 34)

Manajemen dan struktur organisasi masjid bergantung kepada kesepakatan dan mekanisme kerja yang dipengaruhi oleh program pembinaan dan wilayah kerjanya. Wilayah kerja atau area pembinaan ini dapat disesuaikan dengan unit organisasi dalam pemerintahan, seperti tingkat desa, kelurahan, kecamatan, kabupaten, dan seterusnya.

\section{PENUTUP}

Kehidupan masyarakat Desa Batu yang rata-rata petani masih kurang pengetahuan agama sehingga kegiatan ibadah di masjid hanya dilakukan pada hari Jumat. Kegiatan berjamaah juga hanya dilakukan pada saat salat subuh, magrib, dan isya dengan jamaah yang sangan minim.

Peran dan fungsi masjid Aqsha Desa Batu Kecamatan Tapango belum terprogram dalam hal peningkatan kualitas hidup masyarakat karena masjid Aqsha hanya digunakan untuk kegiatan salat lima waktu dan salat Jumat. Kurang maksimalnya kegiatan masjid Aqsha karena kurangnya pengetahuan pengurus masjid tentang manajemen masjid. Di samping itu, SDM pengurus dan perangkat masjid yang masih rendah, kurangnya koordinasi antarpengurus, takmir masjid dan pemerintah setempat.

Peningkatan kualitas bangunan masjid Aqsha sudah sangat mendukung karena telah diadakan renovasi secara total sehingga kegiatan pengembangan kualitas jamaah dan masyarakat Desa Batu, Kecamatan Tapango sudah bisa dilaksanakan. Kegiatan-kegiatan yang bisa dilaksankan berupa pembentukan lembaga keuangan simpan pinjam, pengembangan kegiatan pendidikan untuk jamaah dan anak-anak, yakni TPA, majelis taklim.

Agar jamaah dan pengurus masjid Aqsha Desa Batu Kecamatan Tapango dapat meningkatkan kualitas pengetahuannya, maka perlu diadakan kegiatan ilmiah sehuingga dapat menumbuhkan kesadaran religious pada masayrakat untuk salat di masjid. Pengurus masjid bersama jamaah masjid hendaknya membuat program tentang peningkatan kualitas dan kuantitas jamaah, membuat papan program peningkatan kualitas dan kuantitas masjid dan jamaah.

IImu Dakwah: Academic Journal for Homiletic Studies, Vol. 10 No.2 | Juli-Des 2016237 
Pengurus Masjid Al-Aqso hendaknya melakukan pembenahan fasilats masjid, sehingg dapat menunjang peningkatan kualitas dan kuantitas serta kesejahteraan pengurus dan jamaah. Pengurus masjid mestinya melakukan koordinasi dengan jamaah masjid, kepala desa, KUA, sehingga peran dan fungsi masjid dapat ditingkatkan.

\section{DAFTAR PUSTAKA}

Amrudin, dan Teuku Supardi , 2001, Manajemen Masjid dalam Pembangunan Masyarakat, Optimalisasi Peran dan Fungsi Masjid, (Yogyakarta: UII Press)

Aqil Ibn, Al-Ffiyah Ibn Malik, 1971 (Kairo: Dar al-kutb Al- Arabiy,)

Arikunto, Suharsimi. 2006, Prosedur Penelitian suatu Pendekatan Praktik. Jakarta: PT Rineka Cipta.

Bogdan, Robert C. 1982. Qualitative Research for Education to Thoery and Methods.Boston: Allyn and Bacon.

Creswell, John W. 1994. Research Design.London: SAGE Publications.

Farid Miftah, 1997. Masyarakat Ideal, (Bandung: Pustaka,)

Manzhur Ibn, Lisan al-Arab, 1976 (Jild 2, Baerut: Dar al-fikr,),

Manzhur Ibn, Lisan Al-Arab, 1967, (Jilid Ke-3, Libanon: Daar Al-Fikr Al-Arobi,),

Miles, Matthew B. dan A. Michael 1992, Huberman.Analisis Data Kualitatif. Terjemahan Tjetjep Rohendi Rohidi.. Jakarta: UI Press.

Muhammad Arni, Komunikasi Organisasi, 2014, Jakarta, PT: Bumi Aksra

Mulyana, Deddy, 2008, Kommunikasi Massa: Kontroversi, Teori, dan Aplikasi, Bandung Widya Padjadjaran.

Pratama, Abdul Aziz Nugraha. 2012. Pemberdayaan Ekonomi Umat Berbasi Masjid di Indonesia. Salatiga: STAIN Salatiga Press.

Rukmana Nana, 2002, Cet. Ke-1, Masjid dan dakwah, (Jakarta: AlMawardi Prima,),

238 Ilmu Dakwah: Academic Journal for Homiletic Studies, Vol. 10 No.2 | Juli-Des 2016 
Simamora Henry, 1995, Manajemen Sumber Daya Manusia, Cet. Ke-1, (Yogyakarta: Bagian Penerbit Sekolah Tinggi Ilmu ekonomi YKPN),

Wijayakusuma M. Karibet dan Yusanto Ismail, Pengantar Manajemen Syariat

Yahya, Yohanes, 2006, Cet. Ke-1, Pengantar Manajemen, Jakarta: Graha Ilmu)

Yakub, Moh. E. dan Kawan-kawan, 2001, Manajemen Masjid, Jakarta: Gema Insan Press.)

Yani, Achmad dan Ismail Satori Achmad, Menuju Masjid Ideal, (Cet. Ke-1, Jakarta: LP2SI, tth) 